\title{
Using Ginger Extract for Synthesis of Metallic Nanoparticles and their Applications in Water Treatment
}

\author{
Ayman Kamal ${ }^{1}$, Sahar Zaki ${ }^{1 *}$ (D), Hassan Shokry ${ }^{2,3}$ iD and Desouky Abd-El-Haleem ${ }^{1}$ \\ ${ }^{1}$ Environmental Biotechnology Department, Genetic Engineering and Biotechnology Research Institute, City \\ of Scientific Research and Technological Applications, 21934 New Burgelarab, Alexandria, Egypt. ${ }^{2}$ Electronic \\ Materials Researches Department, Advanced Technology and New Materials Research Institute.City of \\ Scientific Research and Technological Applications, New Borg El-Arab City, Alexanderia, Egypt. ${ }^{3}$ Environmental \\ Engineering Department, Egypt-Japan University of Science and Technology (E-JUST), New Borg El-Arab City, \\ Egypt.
}

\begin{abstract}
The chemical and physical methods for nanoparticle production are relatively expensive and complicated, let alone their toxicity for the ecosystem. On the contrary, using ginger to reduce metal ions into nanoparticles is a more easier and rapid technique, as ginger contains reducing agents; e.g., alkaloids, and phenolic compounds. We synthesized Silver, Copper and Nickel nanoparticles using ginger extract and characterized them by Transmission Electron micrograph, X-ray diffraction, and UV-Vis spectrophotometer. Different concentrations of Silver, Copper and Nickel nanoparticles (100, $200,300,400,500 \mathrm{mg} / \mathrm{ml}$ ) were tested on some chemicals and the microbial content of two water samples [(Brackish lake (Mariout), El Kilo 21 lake)] Alexandria. We concluded that the addition of 100 $\mu \mathrm{l}$ of copper, $50 \mu \mathrm{l}$ of silver, and $\mathbf{1 5 0} \mu \mathrm{l}$ of Nickel nanoparticles / $50 \mathrm{ml}$ of the water sample removed the total content of nitrate and phosphate efficiently, whereas $30 \mu \mathrm{l}$ of copper, $30 \mu \mathrm{l}$ of silver and 75 $\mu \mathrm{l}$ of Nickel nanoparticle / $50 \mathrm{ml}$ of the water sample totally inhibited bacterial contamination. This demonstrates that the preparation of Silver, Copper and Nickel nanoparticles using ginger extract is a safe, easy and economic technique, in addition to being effective in water decontamination and environmental applications.
\end{abstract}

Keywords: Ginger, Nanoparticles, water treatment, XRD, TEM

\footnotetext{
*Correspondence: saharzaki@yahoo.com

(Received: January 28, 2020; accepted: May 07, 2020)

Citation: Kamal A, Zaki S, Shokry H, Abd-El-Haleem D. Using Ginger Extract for Synthesis of Metallic Nanoparticles and their Applications in Water Treatment. J Pure App/ Microbiol. 2020;14(2):1227-1236. doi: 10.22207/JPAM.14.2.17

(C) The Author(s) 2020. Open Access. This article is distributed under the terms of the Creative Commons Attribution 4.0 International License which permits unrestricted use, sharing, distribution, and reproduction in any medium, provided you give appropriate credit to the original author(s) and the source, provide a link to the Creative Commons license, and indicate if changes were made.
} 


\section{INTRODUCTION}

In the past few years nanomaterials have attracted good attention due to their exceptional physical, chemical, and biological properties, which led to them having many applications in different fields, e.g., biomedicine, drug delivery, optics, environment, catalysis, food industry, agriculture, and water treatment (Khalil et al. 2013). Different physical and chemical processes are currently widely used to synthesize nanoparticles, those methods are usually expensive, laborintensive, and they are potentially hazardous to living organisms when used in environmental applications (Popescu et al., 2010). Synthesis of nanoparticles using plant extracts showed important advantages over other biological methods, thanks to the low cost of cultivation, short production time, safety, and the facility to up production volumes (Kumar and Yadav, 2009). Nanoparticles of silver, gold and platinum have been reported to be synthesized by using extracts of plant parts such as onions, lemons grass, neem leaves (Soundarrajan et al., 2012) and others various plant metabolites, including terpenoids, polyphenols, sugars, flavonoids alkaloids, phenolic acids, and proteins, which play an important role in the bioreduction of metal ions (Shiv Shankar et al., 2003; Shiv Shankar et al., 2004; Vilchis-Nestor et al.,2008; Song and Kim, 2009). Zingiber officinale has many phytochemical compounds such as saponins, Flavonoids, Terpenoids, Phlobotanins, Alkaloids, and Tannins Glycosides, which could play an important role in metal reduction to metal nanoparticles (Bhargava et al., 2012 and El-Refai et al., 2018).

Decontamination and disinfection of water and waste water is the most important field in environmental science. The quality of water is dependent on the basis of color, odor, and taste, as well as the level of chemical components, like heavy metals, nitrite, nitrate and phosphate. According to the Environmental Protection Agency, the total amount of phosphate should not exceed $0.05 \mathrm{mg} / \mathrm{L}$ in water (Lakshmanan et al., 2014). High levels of Phosphate - more than $1.0 \mathrm{mg} / \mathrm{L}$ - may interfere with the coagulation in water treatment plants, or cause human diseases for vital organs such as the heart, lungs, kidneys, and liver as well as thyroid gland problems (Lakshmanan and Rajarao, 2014).
Also, high concentrations of nitrate - more than $10 \mathrm{mg} / \mathrm{L}$ - in water are a serious warning to human health, resulting in, "blue baby syndrome" in infants, liver damage, and bladder and ovary cancers (Kapoorand Viraraghavan, 1997). A number of techniques were used for water treatment, such as chemical and physical treatment; also Halogens such as chlorine and bromine are well known and widely used as antibacterial agent, Furthermore, various classes of nano-materials are used for water and wastewater treatment (Anjum et al., 2016).

In this study we used ginger extract as a rapid and simple method for the preparation of nanomaterials, which is a safe, easy and economic technique in water treatment in addition to being effective in environmental applications.

\section{MATERIAL AND METHODS \\ Preparation of the ginger extract}

Ginger roots were dried in an oven at $40^{\circ} \mathrm{C}$ for 24 hours then powdered in a blender; $10 \mathrm{gm}$ of fine powder was mixed with $100 \mathrm{ml}$ distilled water and placed on a magnetic stirrer for 1 hour, centrifuged at $12000 \mathrm{rpm}$ for 30 minute. The supernatant used for synthesis of nanoparticles.

\section{Preparation of metals nanoparticles}

The ginger extract was added dropwise, slowly to $1 \mathrm{mM}$ of copper nitrate $\mathrm{Cu}(\mathrm{NO} 3)_{2} 3 \mathrm{H}_{2} \mathrm{O}$, silver nitrate $\mathrm{AgNO}_{3}$ and Nickle nitrate $\mathrm{Ni}(\mathrm{NO} 3)_{2}$. $6 \mathrm{H}_{2} \mathrm{O}$ (Sigma-Aldrich) on a magnetic stirrer and then placed in a shaker at room temperature for 24 hours. (Yang et al., 2017)

\section{Characterization of metallic nanoparticles Optical Characteristics}

Metal nanoparticles were optically characterized using UV-Visible. Two milliliter from different metallic nanoparticles solutions were measured by visible spectroscopy (Schimadzu UV-Visible spectrophotometer, model UV-1800), the spectrum was measured at room temperature (Zakiet al., 2011).

\section{X-ray diffraction}

Samples were cast on glass slides and dried at ambient temperature, and then the glass slides were fixed on copper supports. 50 milliliters of different metallic nanoparticles solutions were dried at $40^{\circ} \mathrm{C}$ in an oven for 24 hours, then a microscopic slide was coated by the fine powder and analyzed by an X-ray Diffractometer 
Kama et al. | J Pure App Microbiol | 14(2):1227-1236 | June 2020 | https://doi.org/10.22207/JPAM.14.2.17

(Schimadzu-7000, USA), at a rotating anode operating at $30 \mathrm{kV}$ and $30 \mathrm{~mA}$ with a copper target and pikes appearing between $10^{\circ}$ and $80^{\circ}$ in $2 \theta$ (Kaki et al., 2011).

Dispersive X-ray Spectra (EDX)

Qualitative and quantitative analysis and elemental mapping of the produced nanoclusters were determined using a special unit called energy-dispersive spectroscopy (EDS), which is equipped with the scanning electron microscope described above. 50 milliliter of different metallic nanoparticles solution were centrifuged and cells were dried in an oven at $37^{\circ} \mathrm{C}$ for 48 hour after and The EDX analysis was performed by the EDX unit for element analysis in Scanning electron microscope (JEO-100 CX), of Faculty of Science Alexandria University, Egypt (Kaki et al., 2014).
Transmission electron microscope

Transmission electron microscope (JEOL JEM-1230, Japan) was utilized to confirm and prove the morphology. Metal nanoparticles solutions were harvested by centrifuge, and fixed by fixative solution $3 \%$ glutaraldehyde in $0.1 \mathrm{M}$ sodium cocodylate buffer, $\mathrm{PH} 7.2$ for $2 \mathrm{~h}$. and postfixed with $1 \%$ osmium tetra oxide in the same buffer for $1 \mathrm{~h}$ at $4^{\circ} \mathrm{C}$ until it was dehydrated in graded ethanol series and embedded in Exon 812. And then Exon was cut by glass knives. Ultrasections were then examined with transmission electron microscope (JEO-100 CX), Faculty of Science, Alexandria University, Egypt (Kama et al., 2016).
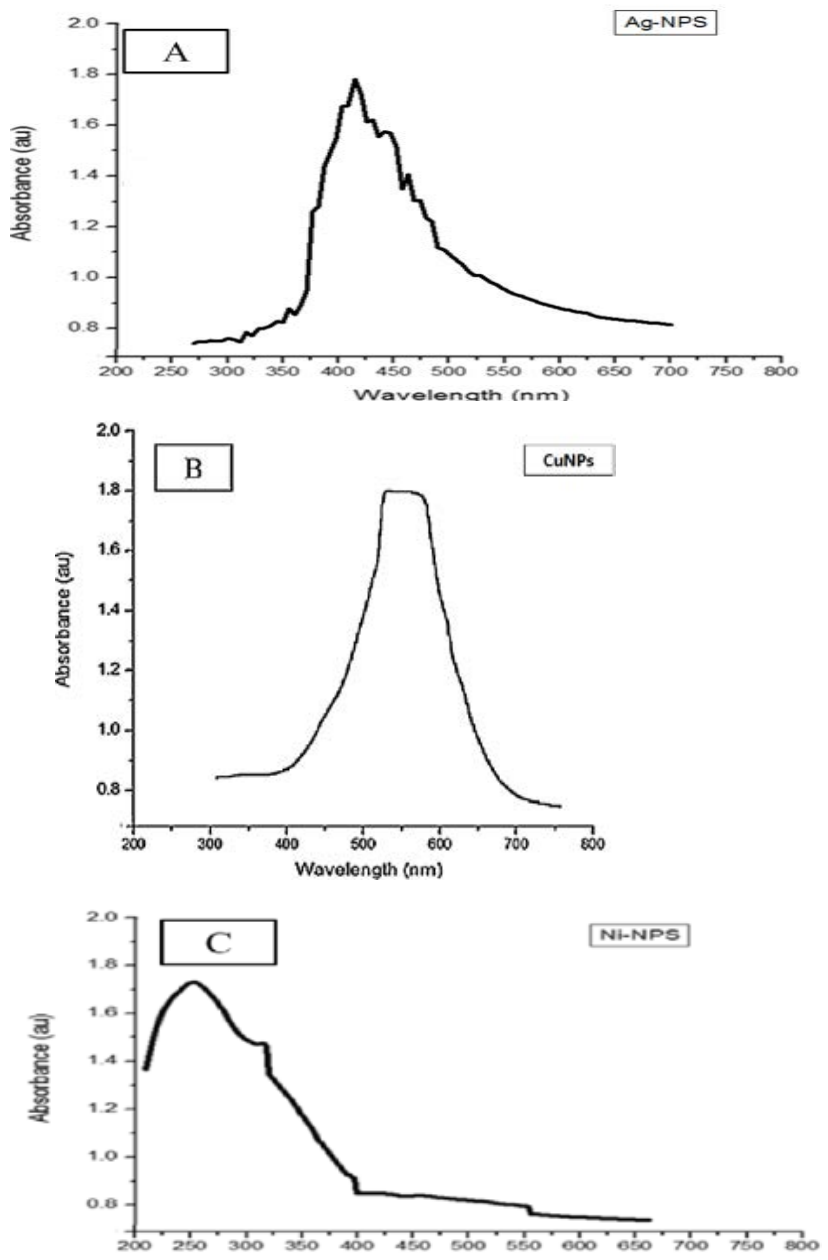

Fig. 1. UV-visible analysis for Ag-NPS (A), CU-NPS (B), Ni-NPS (C), synthesized by ginger.

Journal of Pure and Applied Microbiology

1229

www.microbiologyjournal.org 


\section{Water samples \\ Sampling}

Water samples were collected from of the Brackish Lake (Mariout), El Kilo 21 Lake. Alexandria in April 2017. They were collected in sterilized containers and stored at $4^{\circ} \mathrm{C}$.

\section{Physiochemical analysis of water}

All Physical and chemical analyses were performed according to Standard Methods for the Examination of Water and Waste water $22^{\text {nd }}$ Edition, 2012, American public health association. Water samples treatment

Two water samples were treated with different concentrations $(25,50,75,100,150 \mu l)$ from metal nanoparticles and incubated at $30^{\circ} \mathrm{C}$ for 3 hours.
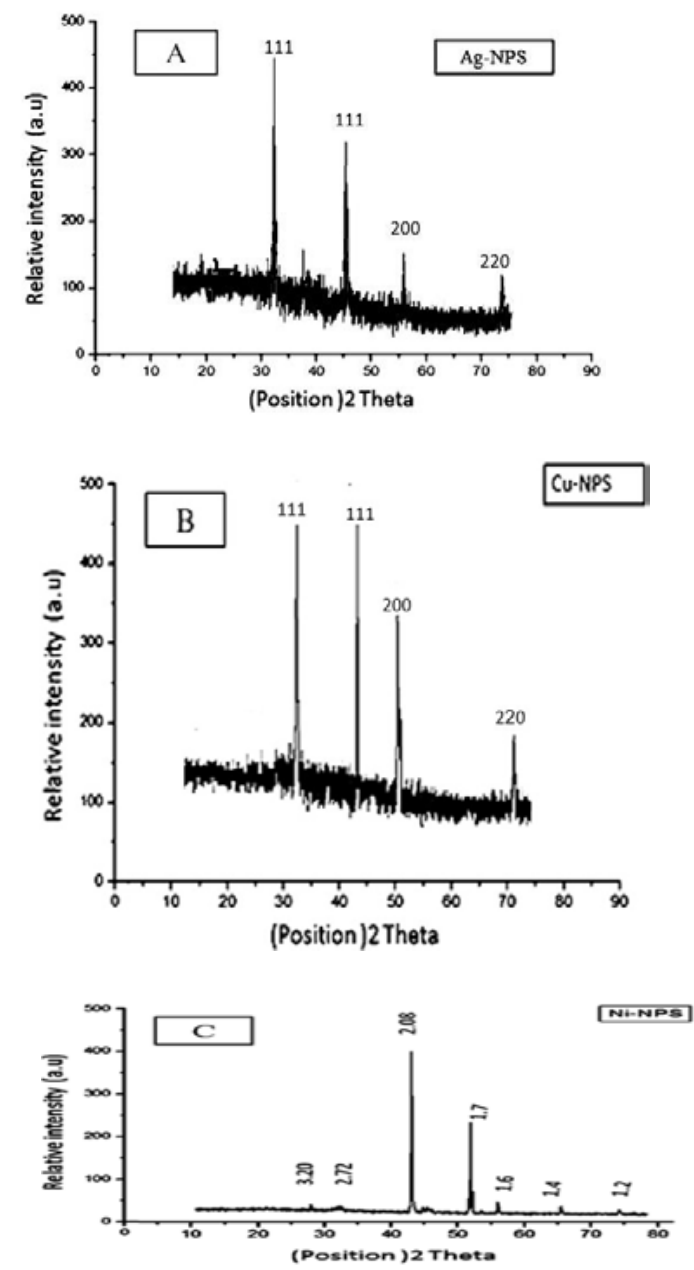

\section{Antibacterial assay}

To determine the nanoparticles' concentrations that are sufficient to disinfect bacteria, Water samples were serially diluted in sterile $0.8 \% \mathrm{NaCl}$ solution and $0.5 \mathrm{ml}$ of first 4 dilutions were spread on Mueller-Hinton Agar plates containing ( $2.0 \mathrm{~g}$ yeast extract, $17.5 \mathrm{~g}$ casein hydrolysate, $1.5 \mathrm{~g}$ starch, $17.0 \mathrm{~g}$ agar) / liter and incubated for $24 \mathrm{~h}$ at $30^{\circ} \mathrm{C}$. After the incubation period, Bacterial colonies were counted after and before incubation with metals-NPS.

The Effect of NPs on the physicochemical parameters of water samples:

The physicochemical criteria of two different real samples were examined before and after their treatment using NPS fora $3 \mathrm{~h}$ incubation, under room temperature to mimic the real

Fig. 2. XRD analysis for Ag-NPS, CU-NPS, Ni-NPS, synthesized by ginger 
environmental conditions in winter and summer. All experiments were performed according to the standard methods described in ABHA 1995.

\section{Results and dissection}

\section{Characterization of metallic nanoparticles}

Optical Characteristics

The UV-Vis spectrum of the ability of ginger extract to reduce the metal salts and form Ag-NPS, CU-NPS, and Ni-NPS, the spectral analysis shows in Fig. 1A represented UV-Vis spectra of the silver nanoparticles in range of $200-800$ the surface Plasmon peak that occurs at $427 \mathrm{~nm}$ (Zaki et al., 2011) with intensity $1.8 \mathrm{au}$. This shift may refer to particle size and shape, the typical silver nanoparticle absorption band in the visible region between 350 and $460 \mathrm{~nm}$. The UV-Vis spectra of copper Nano particle shown in Fig. 1B displayed an absorption peak at around $550 \mathrm{~nm}$ with intensity $1.7 \mathrm{au}$. This peak was investigated for the absorption of copper nanoparticles and confirmed the formation of metal NPs. (Vorobyova et al., 1999, Salavati Niasariand Davar, 2009). The

Table 1. EDS analysis of Ag-NPS, CU-NPS, Ni-NPS Synthesized by ginger

\begin{tabular}{lccccc}
\hline \multirow{2}{*}{ NPS } & \multicolumn{5}{c}{ Elements (\% atomic) } \\
\cline { 2 - 5 } & $\mathrm{Ag}$ & $\mathrm{Cu}$ & $\mathrm{Ni}$ & $\mathrm{O}$ & $\mathrm{N}$ \\
\hline Ag-NPS & 31.1 & 0 & 0 & 5.8 & 10.2 \\
Cu-NPS & 0 & 25.2 & 0 & 4.6 & 6.3 \\
Ni-NPS & 0 & 0 & 18.1 & 5.8 & 10.2 \\
\hline
\end{tabular}
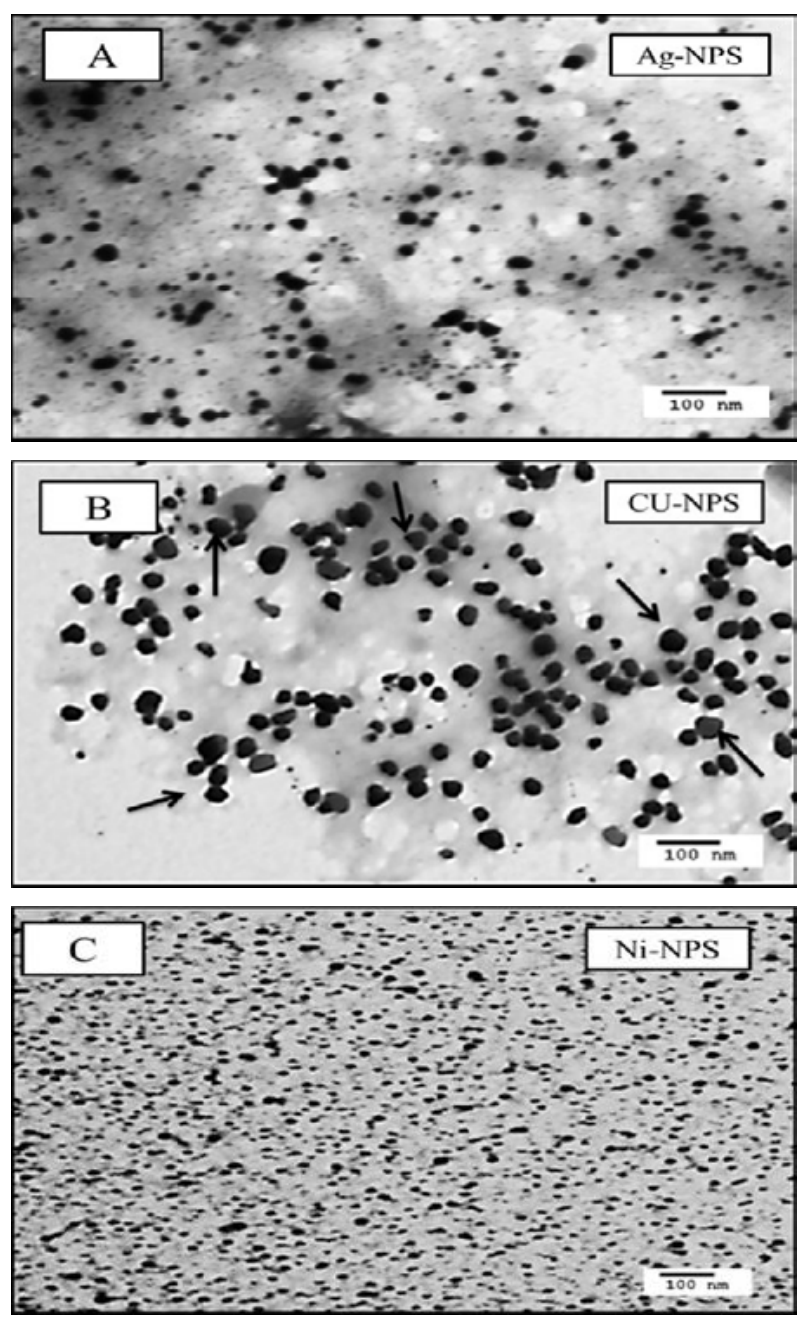

Fig. 3. TEM analysis for Ag-NPS, CU-NPS, Ni-NPS, synthesized by ginger. 
Table 2. Effect of Ag-NPS, CU-NPS, Ni-NPS, synthesized by ginger on bacterial content of El Kilo21 lake water sample

\begin{tabular}{lcccccc}
\hline $\begin{array}{l}\text { Concen. 300 } \\
\text { mg/ml NPS }\end{array}$ & $\begin{array}{c}\text { Count } \\
\text { CFU/ml }\end{array}$ & $\begin{array}{c}25 \\
\mu l\end{array}$ & $\begin{array}{c}30 \\
\mu l\end{array}$ & $\begin{array}{c}75 \\
\mu l\end{array}$ & $\begin{array}{c}150 \\
\mu l\end{array}$ \\
\hline Ag-NPS & 982 & 113 & 0.0 & 0.0 & 0.0 & 0.0 \\
Cu-NPS & 982 & 103 & 0.0 & 0.0 & 0.0 & 0.0 \\
Ni-NPS & 982 & 253 & 108 & 0.0 & 0.0 & 0.0 \\
\hline
\end{tabular}

Table 3. Effect of Ag-NPS, CU-NPS, Ni-NPS, synthesized by ginger on bacterial content of Mariout lake water sample

\begin{tabular}{lcccccc}
\hline $\begin{array}{l}\text { Concen.300 } \\
\mathrm{mg} / \mathrm{ml} \mathrm{NPS}\end{array}$ & $\begin{array}{c}\text { Count } \\
\text { CFU/ml }\end{array}$ & $\begin{array}{c}25 \\
\mu \mathrm{l}\end{array}$ & $\begin{array}{c}30 \\
\mu \mathrm{l}\end{array}$ & $\begin{array}{c}75 \\
\mu \mathrm{l}\end{array}$ & $\begin{array}{c}100 \\
\mu l\end{array}$ & $\begin{array}{c}150 \\
\mu \mathrm{l}\end{array}$ \\
\hline Ag-NPS & 687 & 106 & 0.0 & 0.0 & 0.0 & 0.0 \\
Cu-NPS & 687 & 261 & 0.0 & 0.0 & 0.0 & 0.0 \\
Ni-NPS & 687 & 201 & 121 & 0.0 & 0.0 & 0.0 \\
\hline
\end{tabular}

absorbance was recorded from 200 to $650 \mathrm{~nm}$ in Fig. $1 \mathrm{C}$ and the results had the higher absorbance peak at around $250 \mathrm{~nm}$ with intensity 1.7 au which indicates the conversion of Nickel salt solution to Ni nanoparticles (Gangadhara et al., 2014; Pandian et al., 2015).

\section{$\mathrm{X}$-ray diffraction}

The nanoparticles synthesized using ginger extract are characterized using powder XRD to confirm the crystalline structure of particles in nano form and to know the structural information. Fig. 2A shows the XRD pattern of silver nanoparticles that were recorded from $20^{\circ} \mathrm{C}$ to $100^{\circ} \mathrm{C}$ and it showed sharp peaks, clearly distinguishable and broad, which indicates the ultra-fine nature and small crystallite size. The main peaks are at (20) angles 33, 36, 46, 56, 65, 74, by comparing JCPDS Cards No. 00-004-0783 and No. 00-041-1402). All diffraction peaks correspond to the characteristic face centered cubic (FCC), the typical pattern of AgNPs. It was indicated that there were different orientation planes of silver nanoparticles (Abbasi et al.,2014; Sudha et al., 2013). The slight shift in the peak positions indicated the presence of residual ginger extract in the crystalline structure which is characteristic of nanocrystallites. The XRD of copper nanoparticles - in Fig. 2B - shows three main characteristic diffraction peaks for Cuat around $2 \theta=30^{\circ}, 40,50^{\circ}, 75^{\circ}$ corresponding to Crystallographic planes of face-centred cubic (FCC) Cu crystals (Ramyadevi et al., 2012; Subhankari et al., 2013 and Chaudhary et al., 2017) (JCPDS No.04-0784) the XRD patterns of nickel nanoparticles were shown in Fig. (2C) with different peaks at $(2 \theta) 43^{\circ}, 53^{\circ}, 57^{\circ}, 66^{\circ}, 75^{\circ}$ angles were compared with The JCPDS number 89-7129 indicates the presence of Ni NPs (Chandra et al., 2014; Gangadhara and Subashini, 2014).

Table 4. Effect of Ag-NPS, CU-NPS, Ni-NPS, synthesized by ginger on chemical and physical properties of El Kilo21 lake water sample

\begin{tabular}{|c|c|c|c|c|c|c|c|}
\hline NP-S & $\begin{array}{l}\text { Concen. } 300 \mathrm{mg} / \mathrm{ml} \\
\text { Chemical Content }\end{array}$ & Count & $25 \mu \mathrm{l}$ & $50 \mu \mathrm{l}$ & $75 \mu \mathrm{l}$ & $100 \mu \mathrm{l}$ & $150 \mu \mathrm{l}$ \\
\hline \multirow{5}{*}{ Ag-NPS } & $\mathrm{NO3}$ (mg/ml) & 3.32 & 3.31 & 0.11 & 1.3 & 1.6 & 2.5 \\
\hline & $\mathrm{PO} 4(\mathrm{mg} / \mathrm{ml})$ & 4.53 & 2.46 & 0.95 & 1.9 & 3.3 & 3.1 \\
\hline & TDS (mg/ml) & 4972 & 3812 & 3215 & 3781 & 3651 & 5011 \\
\hline & $\mathrm{EC}(\mu \mathrm{s} / \mathrm{mc})$ & 5441 & 5738 & 5482 & 5921 & 5426 & 5931 \\
\hline & $\mathrm{pH}$ & 7.2 & 7.3 & 7.2 & 7.7 & 7.4 & 8.9 \\
\hline \multirow{5}{*}{ CU-NPS } & NO3 (mg/ml) & 4.32 & 3.11 & 2.14 & 1.2 & 1.8 & 0.0 \\
\hline & $\mathrm{PO} 4$ (mg/ml) & 4.53 & 3.95 & 3.55 & 3.7 & 2.9 & 0.0 \\
\hline & TDS (mg/ml) & 4972 & 4912 & 4915 & 4981 & 4951 & 5921 \\
\hline & $\mathrm{EC}(\mu \mathrm{s} / \mathrm{mc})$ & 5441 & 5956 & 5462 & 5851 & 5446 & 5441 \\
\hline & $\mathrm{pH}$ & 7.2 & 7.1 & 7.6 & 7.1 & 7.9 & 6.6 \\
\hline \multirow{5}{*}{ Ni-NPS } & NO3 (mg/ml) & 4.32 & 3.31 & 3.11 & 1.9 & 1.9 & 0.0 \\
\hline & $\mathrm{PO} 4(\mathrm{mg} / \mathrm{ml})$ & 4.53 & 3.45 & 3.15 & 2.4 & 2.3 & 0.0 \\
\hline & TDS (mg/ml) & 4972 & 4912 & 4915 & 4781 & 4951 & 5821 \\
\hline & $\mathrm{EC}(\mu \mathrm{s} / \mathrm{mc})$ & 5441 & 5936 & 5412 & 5821 & 5326 & 5231 \\
\hline & $\mathrm{pH}$ & 7.2 & 7.4 & 7.6 & 7.2 & 7.3 & 6.8 \\
\hline
\end{tabular}


Table 5. Effect of Ag-NPS, CU-NPS, Ni-NPS, synthesized by ginger on chemical and physical properties of Mariout lake water sample

\begin{tabular}{llcccccc}
\hline NP-S & $\begin{array}{l}\text { Conc. } 300 \mathrm{mg} / \mathrm{ml} \\
\text { Chemical content }\end{array}$ & Count & $150 \mu \mathrm{l}$ & $100 \mu \mathrm{l}$ & $75 \mu \mathrm{l}$ & $50 \mu \mathrm{l}$ & $25 \mu \mathrm{l}$ \\
& & & & & & \\
\hline \multirow{5}{*}{ Ag-NPS } & NO3 $(\mathrm{mg} / \mathrm{ml})$ & 4.32 & 3.4 & 2.9 & 1.7 & 00 & 2.21 \\
& PO4 $(\mathrm{mg} / \mathrm{ml})$ & 3.86 & 3.0 & 3.2 & 2.9 & 0.11 & 1.6 \\
& TDS $(\mathrm{mg} / \mathrm{ml})$ & 3982 & 3821 & 3041 & 3621 & 3835 & 3602 \\
& EC $(\mu \mathrm{s} / \mathrm{mc})$ & 4231 & 5231 & 5526 & 5311 & 4112 & 4116 \\
& pH & 7.8 & 8.8 & 7.3 & 7.2 & 7.1 & 7.6 \\
& NO3 $(\mathrm{mg} / \mathrm{ml})$ & 4.32 & 0.0 & 0.0 & 1.9 & 3.11 & 3.31 \\
& PO4 $(\mathrm{mg} / \mathrm{ml})$ & 3.86 & 0.0 & 0.0 & 2.4 & 3.15 & 3.45 \\
& TDS $(\mathrm{mg} / \mathrm{ml})$ & 3982 & 1400 & 1132 & 1352 & 1265 & 1125 \\
& EC $(\mu \mathrm{s} / \mathrm{mc})$ & 4231 & 5898 & 4521 & 4331 & 4421 & 4621 \\
& pH & 7.8 & 7.3 & 7.9 & 8.2 & 8.6 & 8.6 \\
& NO3 $(\mathrm{mg} / \mathrm{ml})$ & 4.32 & 0.0 & 1.8 & 1.2 & 2.14 & 3.11 \\
& PO4 $(\mathrm{mg} / \mathrm{ml})$ & 3.86 & 0.0 & 2.9 & 3.7 & 3.55 & 3.95 \\
& TDS $(\mathrm{mg} / \mathrm{ml})$ & 3982 & 3621 & 3551 & 3481 & 3515 & 3612 \\
& EC $(\mu \mathrm{s} / \mathrm{mc})$ & 4231 & 5441 & 5446 & 5851 & 5462 & 5956 \\
& pH & 7.8 & 6.6 & 7.9 & 7.1 & 7.6 & 7.1 \\
\hline
\end{tabular}

\section{Dispersive X-ray Spectra (EDX)}

Out of EDS results both UV and XRD analysis were confirmed. Table 1 shows the strong signals of Silver $31.1 \%$, Copper $25.2 \%$, and Nickel18.1\% atoms in the nanoparticles recorded in the energy dispersive $\mathrm{X}$-ray, and other signals from $\mathrm{O} 2$ and $\mathrm{N} 2$ atoms were also observed. It may belongs to the residual ginger extract in agreement with the XRD observation, the data demonstrated that ginger extract has the ability to form nanoparticles (Zaki et al., 2014; Kamal et al., 2016).

\section{Transmission electron microscope}

Fig. 3 shows TEM image obtained with ginger extract and different metal salts. It is shown in Fig. 3A the relatively spherical with smooth surface morphology of silver nanoparticles in range 6-27 $\mathrm{nm}$ (Zaki et al., 2012), while the copper nanoparticles shown in Fig. 3B revealed some unique features of copper nanoparticles (Abboud et al., 2013), as it is demonstrated,copper nanoparticles were formed in Nano triangles and nano hexagons in range $14-45 \mathrm{~nm}$ with attached nanospheres but the majority of them were nanohexagons. The arrows indicate nano-hexagons and Nano triangles of copper nanoparticles, the Nickel nanoparticles shown in Fig. $3 \mathrm{C}$ have an average diameter of 2-5 $\mathrm{nm}$ with a spherical shape (Helen and Rani, 2015).In conclusion the supernatant solutions that confirms the production of nanoparticles extra cellular offer a great advantage over an intracellular process of synthesis from the application point of view. Since the nanoparticles formed inside the biomass would have required additional steps of processing forthe release of the nanoparticles from the biomass by ultrasound treatment or by reaction with suitable detergents.

\section{Water samples treatment \\ Antibacterial assay}

Antibacterial Activity of NPS on natural bacterial contamination of two real samples was shown in table 2, 3; it revealed that $\mathrm{Ag}$ NPS, CU-NPS act as good disinfectants for water in a concentration of $30 \mu \mathrm{l}(300 \mathrm{mg} / \mathrm{ml})$ and totally remove the bacterial count in contrast to count control non-treated samples, also $\mathrm{Ni}$ NPS completely inhibit bacterial growth on a concentration of $75 \mu \mathrm{l}(300 \mathrm{mg} / \mathrm{ml})$. The effect of different Nanoparticles in low concentration corresponds to high surface area and aggregation of particles in high concentrations. The effect and toxicity of Ag-NPS to bacterial cells may be due to the ability of particles to anchor to the bacterial cell and causing internal changes like the effect on cell permeability and formation of 'pits' in the cell wall. Also, the formation of free radicals when in contact with cells leads to cell's death. It has 
also been proposed that Ag-NPS produce silver ions which cause the inhibition of a respiratory enzyme and interact with the thiol groups of many enzymes and inhibit them (Morones et al., 2005; Hatchett and Henry, 1996). Another fact is destroying the DNA by interacting with sulfur and phosphorus bases (Sondi and Salopek-Sondi, 2004). On the other hand, several studies reported that there are different mechanisms for the toxicity of CU-NPS on the bacterial cells included protein oxidation, lipid peroxidation, DNA degradation, generation of reactive oxygen and mediated dissipation of cell membrane, causing the formation of cell filaments (Chatterjee et al., 2014). Many researchers reported different mechanisms of the antibacterial effect of Ni-NPS summarized in generation of ROS and release of nickel ions $\left(\mathrm{Ni}^{+}\right)$, destroying membrane proteins, interrupting membrane permeability, cytoplasmic leakage, interrupting electron transport in the microbial cell (Ravindhranath and Ramamoortyamamoorty, 2017). As well (Chaudhary et al., 2019) reported that antimicrobial activities of Nickel and Copper nanoparticles against Escherichia coli, Klebsiella pneumoniae and Pneumonia Typhus, have shown appreciable sensitivity at $100 \mu \mathrm{g} / \mathrm{ml}$ against all test micro-organisms also (Gayathri et al.,2019) Studied The antimicrobial activity of nickel-doped copper ferrite was tested against Escherichia coli, Klebsiella pneumonia, Staphylococcus aureus, Bacillus subtilis and it showed an excellent results Physiochemical analysis

The Tables 4, 5 showed the effect of metal nanoparticles on the physiochemical properties of two real water samples and it demonstrated that a low concentration of silver nanoparticle 50 $\mu \mathrm{l}$ was more efficient for nitrate and phosphate removal as reported previously in (Zhang et al., 2016), while high concentration increased aggregation between nanoparticles, reduced the surface area which would reduce the particles reaction. The decrease of water content from nitrate may be the role of nitrification inhibition action of silver nanoparticles. Previous studies concluded that silver nanoparticles have more detrimental to nitrifying organisms that involved in nitrification cycle with the nitrate as end product of cycle (Choi and Hu, 2009). On the other hand, silver nanoparticles were more effective for phosphate removal, also it was shown that a 95-
99\% phosphate removal efficiency is gained by using Ag-Fe nanoparticles as phosphate adsorbent (Vilardi and Di Palma, 2017).

Copper nanoparticles were effective in phosphate and nitrate removal, and increasing with high concentration up to $150 \mu \mathrm{l}$ it may be due to the large external surface adsorption area and its role in nitrate removal enhancing the redox performances by the catalytic action (Mahdavi and Akhzari, 2015). several studies reported that Bimetallic nano-Fe/Cu particles were used to reduce nitrates in aquatic solutions by increasing the development of nitrogen gas thus lowering ammonium production, and it may enhance the rate of nitrate reduction in aqueous solution by favouring the electron transfer (Muradova et al., 2016). The role of copper nanoparticles in phosphate removal may be due to their porous structures, high surface areas, easy operation and preferred surface properties.

Also nickel nanoparticles were totally removing phosphate and nitrate in $150 \mu \mathrm{l}$. Many studies reported that Nickel nanoparticles act as good adsorbents for Pollutants in water due to their biocompatibility and chemical properties; also a combination of Nickel nanoparticles with iron and cobalt nanoparticles and graphene oxide has more efficiency in the removal of nitrate from water and acts as a stronger catalyst (Liu et al., 2016). Several studies reported that the removal of pollutants like nitrate and phosphate decreased with an increase in the initial solution's pH value. Different studies reported that nitrate removal was increased in the $\mathrm{pH}$ range of 6.5-8.0 (Liu et al., 2016). On the other hand, the effect of Ag-NPS, CU-NPS, Ni-NPS, synthesized by ginger, on electric conductivity two water samples were shown in Fig. $(4,5)$ and it is concluded that electrical conductivity increases with nanoparticles treatment and increasing with increase nanoparticles concentration like silver, copper and nickel nanoparticles several studies reported that nanoparticles can improve electrical conductivity of liquids (Taheri, 2015; Steven et al., 2011).

\section{CONCLUSION}

This study concluded that the preparation of Silver, Copper and Nickel nanoparticles using ginger extract was an effective, easy and economic technique in water treatment in addition to 
being effective in water decontamination in addition to other environmental applications. Nanoparticles were characterized by Transmission Electron micrograph, X-ray diffraction, UV-Vis spectrophotometer, and Energy-dispersive X-ray spectroscopy. Different concentrations of Silver, Copper and Nickel nanoparticles $(25,50,75$, $100,150 \mu \mathrm{l}$ ) were tested on some chemicals and the microbial content of two water samples. The results established that $100 \mu \mathrm{l}$ of copper, $50 \mu \mathrm{l}$ of silver, and $150 \mu \mathrm{l}$ of Nickel (nanoparticles) / $50 \mathrm{ml}$ of the water sample removed the total content of nitrate and phosphate efficiently, whereas $30 \mu \mathrm{l}$ of copper nanoparticles, $30 \mu \mathrm{l}$ of silver and $75 \mu \mathrm{l}$ of Nickel (nanoparticle) / $50 \mathrm{ml}$ of the water sample totally inhibited bacterial contamination.

\section{ACKNOWLEDGMENTS}

We would like to thank the technicians at Environmental biotechnology department, Genetic Engineering Institute, City of Scientific Research and Technological Applications, Burgelarab city, Alexandria, Egypt, for the collaboration during the recruitment process.

\section{CONFLICT OF INTEREST}

The authors declare that there is no conflict of interest.

\section{AUTHORS' CONTRIBUTION}

The authors AK, SZ and DA contributed to plan of the wok, results explanation manuscript writing and data analysis. HSh helped in the physiochemical properties explanation.

\section{FUNDING}

This study was supported from Genetic Engineering Institute, City of Scientific Research and Technological Applications, Burgelarab city, Alexandria, Egypt.

\section{ETHICS STATEMENT}

This article does not contain any studies with human participants or animals performed by any of the authors.

\section{DATA AVAILABILITY}

All datasets generated or analyzed during this study are included in the manuscript.

\section{REFERENCES}

1. Abbasi E, M Milani, S Aval, et al. Silver nanoparticles: Synthesis methods, bio-applications and properties. Crit Rev Microbiol. 2014;1:1-8. https://doi.org/10.3109/104 0841X.2014.912200

2. Abboud Y, T Saffaj, A Chagraoui, et al. Biosynthesis, characterization and antimicrobial activity of copper oxide nanoparticles (CONPs) produced using brown alga extract (Bifurcariabifurcata). Appl Nanosci. 2014;4:571576. https://doi.org/10.1007/s13204-013-0233-x

3. Anjum M, M Oves, R Kumar, MA Barakat. Fabrication of $\mathrm{ZnO}-\mathrm{ZnSpolyanilinenanohybrid} \mathrm{for} \mathrm{enhanced}$ photocatalytic degradation of 2-chlorophenol and microbial contaminants in wastewater. Intern Biodeter. Biodeg. 2017;119:66-77. https://doi.org/10.1016/j. ibiod.2016.10.018

4. Bhargava S, K Dhabhai, A Batra, A Sharma, B Malhotra. Zingiber Officinale: Chemical and phytochemical screening and evaluation of its antimicrobial activities. J Chem Pharmaceut Res. 2012;4:360-364.

5. Chandra S, A Kumar, PK Tomar. Synthesis of $\mathrm{Ni}$ nanoparticles and their characterizations. J Saud Chem. Soc. 2014;18:437-442. https://doi.org/10.1016/j. jscs.2011.09.008

6. Chatterjee, A., R. Chakraborty and T. Basu. 2014. Mechanism of antibacterial activity of copper nanoparticles. Nanotechnol. 25:1-12.

7. Choi OK, ZQ Hu. Nitrification inhibition by silver nanoparticles. Water Sci Technol. 2009;59:1699-1702. https://doi.org/10.2166/wst.2009.205

8. Chaudhary J., Tailor G., Kumar D., Joshi A. 2017: Synthesis and thermal properties of copper nanoparticles. Asian J. Chem. ;29(7):1492-1494; Chaudhary, J., Tailor, G., Yadav, B. L., \& Michael, O. 2019:. Synthesis and biological function of Nickel and Copper nanoparticles. Heliyon, 5(6): e01878. https://doi.org/10.1016/j.heliyon.2019. e01878

9. Gangadhara, A., R. Ramya and R. Subashini. 2014. In-vitro anti-inflammatory and mosquito larvicidal efficacy of nickel nanoparticles phytofabricated from aqueous leaf extracts of Aegle marmelos Correa. Acta Trop. 135:1926. Gangadhara, A. and R. Subashini. 2014. A review on nickel nanoparticles as effective therapeutic agents for inflammation. Inflam. Cell. Signal. 1:1-8.

10. El-Refai, A.A., Ghoniem, G.A., El-Khateeb, A.Y:2018. Ecofriendly synthesis of metal nanoparticles using ginger and garlic extracts as biocompatible novel antioxidant and antimicrobial agents. J Nanostruct Chem 8, 71-81 https://doi.org/10.1007/s40097-018-0255-8

11. Gayathri Manju, B., Raji, P. 2019: Biological synthesis, characterization, and antibacterial activity of nickeldoped copper ferrite nanoparticles. Appl. Phys. A 125, 313. https://doi.org/10.1007/s00339-019-2619-4

12. Helen S, M Rani. Characterization and antimicrobial study of nickel nanoparticles synthesized from dioscorea (Elephant Yam) by green route. Inter J Sci Res. 2015;4:216219. https://doi.org/10.21275/v4i11.NOV151105

13. Kamal A, S Zaki G Abu-Elreesh, D Abd-El-Haleem. Biosynthesis and characterization of silver nanoparticles using Metschnikowiapulcherrima strain 29a: their antibacterial, antifungal and bioluminescent toxicity effects against microbial pathogens. Ecol Environ Cons. 
2016;22:27-41.

14. Kapoor A, T Viraraghavan. Nitrate removal from drinking water-review. J Environ Eng. 1997;123:371-380. https:// doi.org/10.1061/(ASCE)0733-9372(1997)123:4(371)

15. Khalil KA, H Fouad T Elsarnagawy, FN Almajhdi. Preparation and characterization of electrospun PLGA/ silver composite nanofibers for biomedical applications. Int J Electrochem Sci. 2013;8:3483-3493.

16. Kumar V, SK Yadav. Plant-mediated synthesis of silver and gold nanoparticles and their applications. J Chem Technol Biotechnol. 2009;84:151-157. https://doi.org/10.1002/ jctb.2023

17. Lakshmanan R, C Okoli, M Boutonnet, S Jaras, G Rajarao. Micro emulsion prepared magnetic nanoparticles for phosphate removal: Time efficient studies. J Environ Chem Eng. 2014;2:185-189. https://doi.org/10.1016/j. jece.2013.12.008

18. Lakshmanan R, G Rajarao. Effective water content reduction in sewage wastewater sludge using magnetic nanoparticles. Bioresource Technol. 2014;153:333-339. https://doi.org/10.1016/j.biortech.2013.12.003

19. Liu Y, S Li, Z Chen, M Megharaj, R Naidu. Influence of zero-valent iron nanoparticles on nitrate removal by Paracoccus sp. Chemosphere. 2014;108:426-43. https:// doi.org/10.1016/j.chemosphere.2014.02.045

20. Mahdavi S, D Akhzari. The removal of phosphate from aqueous solutions using two nano- structures: copper oxide and carbon tubes. Clean Techn Environ Policy. 2016;18:817-827. https://doi.org/10.1007/s10098-0151058-y

21. Morones JR, JL Elechiguerra, A Camacho, et al. The bactericidal effect of silver nanoparticles. Nanotechnol. 2005;16:2346-2353. https://doi.org/10.1088/0957$4484 / 16 / 10 / 059$

22. Muradova G, S Gadjieva, L Palma, G Vilardi. Nitrates removal by bimetallic nanoparticles in water. Chem Eng Trans. 2016;47:205-210.

23. Pandian CJ, R Palanivel, S Dhanasekaran. Green synthesis of nickel nanoparticles using Osmium sanctum and their application in dye and pollutant adsorption. Chin J Chem Eng. 2015;23:1307-1315. https://doi.org/10.1016/j. cjche.2015.05.012

24. Ramyadevi J, Jeyasubramanian K, Marikani A, Rajakumar G, A Rahuman. Synthesis and antimicrobial activity of copper nanoparticles. Mater Lett. 2012;71:114-116. https://doi.org/10.1016/j.matlet.2011.12.055

25. Ravin K, M Ramamoorty. Nickel Based Nano Particles as Adsorbents in Water Purification Methods. Orient J Chem. 2017;33:1603-1613. https://doi.org/10.13005/ ojc/330403

26. Salavati M, F Davar. Synthesis of Copper and Copper (I) Oxide nanoparticles by thermal decomposition of a new precursor. Mater Lett. 2009;63:441-443. https://doi. org/10.1016/j.matlet.2008.11.023

27. Shiv S, A Ahmad, R Pasricha, M Sastry. Bioreduction of chloroaurate ions by geranium leaves and its endophytic fungus yields gold nanoparticles of different shapes. Mater Chem. 2003;13:1822-1846. https://doi. org/10.1039/b303808b

28. Shiv S, A Rai, A Ahmad, M Sastry. Rapid synthesis of $\mathrm{Au}, \mathrm{Ag}$, and bimetallic $\mathrm{Au}$ core-Ag shell nanoparticles using Neem (Azadirachtaindica) leaf broth. J Colloid Interf Sci. 2004;275:496-502. https://doi.org/10.1016/j. jcis.2004.03.003

29. Sondi I, B Salopek-Sondi. Silver nanoparticles as antimicrobial agent: a case study on $\mathrm{E}$. coli as a model for Gram-negative bacteria. J Colloid Interf Sci. 2004;275:177182. https://doi.org/10.1016/j.jcis.2004.02.012

30. Song JY, BS Kim. Rapid biological synthesis of silver nanoparticles using plant leaf extracts. Bioproc. Biosyst Eng. 2009;32:79-84. https://doi.org/10.1007/s00449008-0224-6

31. Soundarrajan C, A Sankari, P Dhandapani, et al. Rapid biological synthesis of platinum nanoparticles using Ocimum sanctum for water electrolysis applications. Bioproc Biosyst Eng. 2012;35:827-833. https://doi. org/10.1007/s00449-011-0666-0

32. Steven BW, J M Albert, PP Kevin. Investigation of the electrical conductivity of propylene glycol-based $\mathrm{ZnO}$ nanofluids. Nanoscale Res Lett. 2011;6:346-351. https:// doi.org/10.1186/1556-276X-6-346

33. Subhankari I, PL Nayak. Antimicrobial Activity of Copper Nanoparticles Synthesised by Ginger (Zingiberofficinale) Extract. World J Nat Sci Technol. 2013;2:10-13.

34. Sudha S, K Rajamanickam, J Rengaramanujam. Microalgae mediated synthesis of silver nanoparticles and their antibacterial activity against pathogenic bacteria. Ind J Experim Biol. 2013;52:393-399.

35. Taheri R. Electrical conductivity of CuO nanofluids. Intern J Nano Dimens. 2015;6:77-81.

36. Vallet-Regi, M., Gonzalez, B., \& Izquierdo-Barba, I. 2019:. Nanomaterials as Promising Alternative in the Infection Treatment. International journal of molecular sciences, 20(15): 3806. https://doi.org/10.3390/ijms20153806

37. Vilardi, G. and L. Palma. 2017. Kinetic Study of Nitrate Removal from Aqueous Solutions Using Copper-Coated Iron Nanoparticles. Bullet. Environ. Contam.Toxicol. 98:359-365.

38. Vorobyova SA, Al Lesnikovich, V Muchinskii. Interphase synthesis and some characteristics of stable colloidal solution of CuO in octane. Physicochem Eng Asp. 1999;15:297-300. https://doi.org/10.1016/S09277757(98)00825-5

39. Yang, N., Li, F., Jian, T. et al. 2017:.Biogenic synthesis of silver nanoparticles using ginger (Zingiber officinale) extract and their antibacterial properties against aquatic pathogens. Acta Oceanol. Sin. 36:95-100 https://doi. org/10.1007/s13131-017-1099-7

40. Zaki S, A Kamal, M Elkady, G Abu-Elreesh, D Abd-ElHaleem. Biosynthesis of silver nanoparticles using Stenotrophomonas rhizophila and its application as a disinfectant agent of water. Europ J Experim Biol. 2014;4:662-669.

41. Zaki S, M Elkady, S Farag, D Abd-EL-Haleem. Determination of the effective origin source for nanosilver particles produced by Escherichia coli strain $\mathrm{S} 78$ and its application as antimicrobial agent. Mat Res Bull. 2012;47:4286-4290. https://doi.org/10.1016/j.materresbull.2012.09.016

42. Zhang X, Z Liu, W Shen, S Gurunathan. Silver Nanoparticles: Synthesis, Characterization, Properties, Applications, and Therapeutic Approaches. Int J Mol Sci. 2016;17:15341560. https://doi.org/10.3390/ijms17091534 